\title{
Article \\ Escherichia coli Antibiotic Resistance Patterns from Co-Grazing and Non-Co-Grazing Livestock and Wildlife Species from Two Farms in the Western Cape, South Africa
}

\author{
Michaela Sannettha van den Honert ${ }^{1,2}$, Pieter Andries Gouws ${ }^{1, *(\mathbb{D})}$ and Louwrens Christiaan Hoffman ${ }^{2,3}$ (D) \\ 1 Centre for Food Safety, Department of Food Science, University of Stellenbosch, Private Bag X1, \\ Matieland 7602, South Africa; michaelavdh@sun.ac.za \\ 2 Department of Animal Sciences, University of Stellenbosch, Private Bag X1, Matieland 7602, South Africa; \\ louwrens.hoffman@uq.edu.au \\ 3 Centre for Nutrition and Food Sciences, Queensland Alliance for Agriculture and Food Innovation, \\ The University of Queensland, Digital Agricultural Building, 8115, Office 110, Gatton 4343, Australia \\ * Correspondence: pgouws@sun.ac.za
}

check for updates

Citation: van den Honert, M.S.; Gouws, P.A.; Hoffman, L.C. Escherichia coli Antibiotic Resistance Patterns from Co-Grazing and Non-Co-Grazing Livestock and Wildlife Species from Two Farms in the Western Cape, South Africa. Antibiotics 2021, 10, 618. https:// doi.org/10.3390/antibiotics10060618

Academic Editor: Antony T. Vincent

Received: 21 April 2021

Accepted: 17 May 2021

Published: 22 May 2021

Publisher's Note: MDPI stays neutral with regard to jurisdictional claims in published maps and institutional affiliations.

Copyright: (C) 2021 by the authors. Licensee MDPI, Basel, Switzerland. This article is an open access article distributed under the terms and conditions of the Creative Commons Attribution (CC BY) license (https:// creativecommons.org/licenses/by/ $4.0 /)$.
Abstract: Although limited, studies have found conflicting results on whether co-grazing results in significant antibiotic resistance transfer between species. This type of farming system can act as a vector in the geographical spread of antibiotic-resistant bacteria in the environment. The aim of this study was to determine the antibiotic-resistant patterns between co-grazing and non-co-grazing livestock and wildlife species in South Africa. Escherichia coli was isolated from the faeces of various wildlife and livestock species from two farms in South Africa and was tested for antibiotic resistance using the Kirby-Bauer disk diffusion method against chloramphenicol, nalidixic acid, ampicillin, streptomycin, sulphafurazole, and tetracycline. A selection of some common antibiotic-resistant genes (blaCMY, aad A1, sul1, sul2, tet $\mathrm{A}$, and tet $\mathrm{B}$ ) were detected using PCR. The E. coli isolates from wildlife and livestock that co-grazed showed no significant differences in antibiotic resistance patterns. However, this was not the case for tetracycline resistance as the livestock isolates were significantly more resistant than the co-grazing wildlife isolates. The E. coli isolates from the non-co-grazing livestock and wildlife had significant differences in their antibiotic susceptibility patterns; the wildlife E. coli isolates were significantly more resistant to sulphafurazole and streptomycin than the livestock isolates, whilst those isolated from the cattle were significantly more resistant to ampicillin than the wildlife and sheep isolates. The results of this study suggest that there could be an exchange of antibiotic-resistant bacteria and genes between livestock and wildlife that co-graze.

Keywords: antimicrobial resistance; disc diffusion; game; ungulate; wildlife; livestock; cattle; sheep

\section{Introduction}

Despite the perception of a low risk of antibiotic resistance developing in natural environments, the studies listed [1] have shown that antibiotic resistance among wild animals is a growing public health issue due to increased wildlife contact between humans, livestock, and domestic animals. It cannot be assumed that microbial communities in natural, more remote environments are completely isolated from external activities and commercial settings [2].

This study focused on the effect that co-grazing livestock and wildlife that live and feed off the same land may have on the development and transfer of antibiotic resistance between the wildlife-livestock interface. In South Africa, 34.3\% of game farmers practised co-grazing of livestock and wildlife [3]. The wildlife-livestock interface is becoming a more common occurrence in animal farming, which is in part due to the increased demand for food and land as well as a direct response to re-wilding.

The transfer of antibiotic-resistant bacteria can be bi-directional at the wildlife-livestock interface, as both species can be sources of antibiotic-resistant bacteria [4-6]. There is 
evidence that transmission of microorganisms, whether it is antibiotic-resistant or diseasecausing microorganisms, occurs between livestock and wildlife, demonstrated by numerous outbreaks of wildlife-associated diseases, such as Foot and Mouth disease and African swine fever, which have spread to domestic livestock [7]. It was found that $41 \%$ of farmers in South Africa who practised co-grazing of livestock and wildlife had no control measures to prevent animal interaction to prevent disease transmission [3]. This is a public health issue, as about $60 \%$ of diseases in humans are zoonotic, with $72 \%$ being of wildlife origin [8].

During co-grazing, direct contact can occur through interspecies contact during the sharing of pastures and water points [7,9] or indirectly, through mobile transfer vectors such as birds or wind $[10,11]$. Differences in contact rates can influence the transmission rate of diseases and bacteria between livestock and wildlife species. For example, in periods of drought, there is more frequent contact at existing water points [12]. These same principles regarding disease transfer also hold true for the exchange of antibiotic-resistant bacteria between co-grazing animals [12].

It was hypothesised that the practice of co-grazing wildlife and livestock influences the antibiotic resistance profiles of Escherichia coli harboured by animal species.

\section{Results}

\subsection{Phenotypic Antibiotic Resistance}

Escherichia coli was isolated from 35 of the 40 faecal samples. Metzler-Zebeli et al. [13] found that freezing animal faecal samples at $-20{ }^{\circ} \mathrm{C}$ had a minimal effect (approximately a 3-6\% loss) on the abundance of Enterobacteriaceae when compared to sampling directly from fresh faecal samples. Escherichia coli was selected for the analysis as it is commonly used as an indicator of antibiotic resistance by other researchers due to its ability to easily acquire and transfer antibiotic resistance genes and because E. coli is a commensal bacterium found in the normal gut flora of animals [14].

Overall, the E. coli isolates from livestock and wildlife species from both farms exhibited low resistance to the range of six antibiotics tested for. The E. coli isolated from the wildlife were, on average, $70 \%$ susceptible, and those isolated from the livestock were, on average, $70 \%$ susceptible to the six antibiotics.

It should be noted that the antibiotic resistance profiles of the E. coli isolates towards nalidixic acid and chloramphenicol were not included in the statistical analysis due to negligible resistance levels detected, leading to no variance in the data.

Figure 1 displays the overall antibiotic resistance levels of E. coli isolated from various animals from the Witsand farm (co-grazing farm) and the Bredasdorp farm (non-cograzing). The springbok (Antidorcas marsupialis) and fallow deer (Dama dama) from the Witsand farm were grouped together as 'wildlife', and the sheep and cattle were grouped together as 'livestock' due to no differences $(p>0.05)$ in their antibiotic susceptibility profiles. Likewise, the eland (Taurotragus ory $x$ ) and wildebeest (Connochaetes gnou) from the Bredasdorp farm were grouped together as 'wildlife' due to no differences $(p>0.05)$ in their antibiotic susceptibility profiles. However, the sheep and cattle were grouped separately due to differences $(p \leq 0.05)$ in their antibiotic susceptibility profiles.

From the Witsand farm (co-grazing), on average, there were no differences $(p>0.05)$ in the antibiotic resistance levels between the co-grazing livestock and wildlife E. coli isolates except towards tetracycline, where the livestock isolates had a significantly higher number of isolates classified as resistant than the wildlife isolates (Figure 1).

From the Bredasdorp farm (no co-grazing), on average, there were differences $(p \leq 0.05)$ in the antibiotic resistance levels between the non-co-grazing livestock and wildlife except towards tetracycline. More specifically, the wildlife E. coli isolates were significantly more frequently classified as resistant to sulphafurazole and streptomycin than the cattle and sheep isolates, and the isolates from the cattle were significantly more frequently classified as resistant to ampicillin than the wildlife and sheep isolates (Figure 1). 


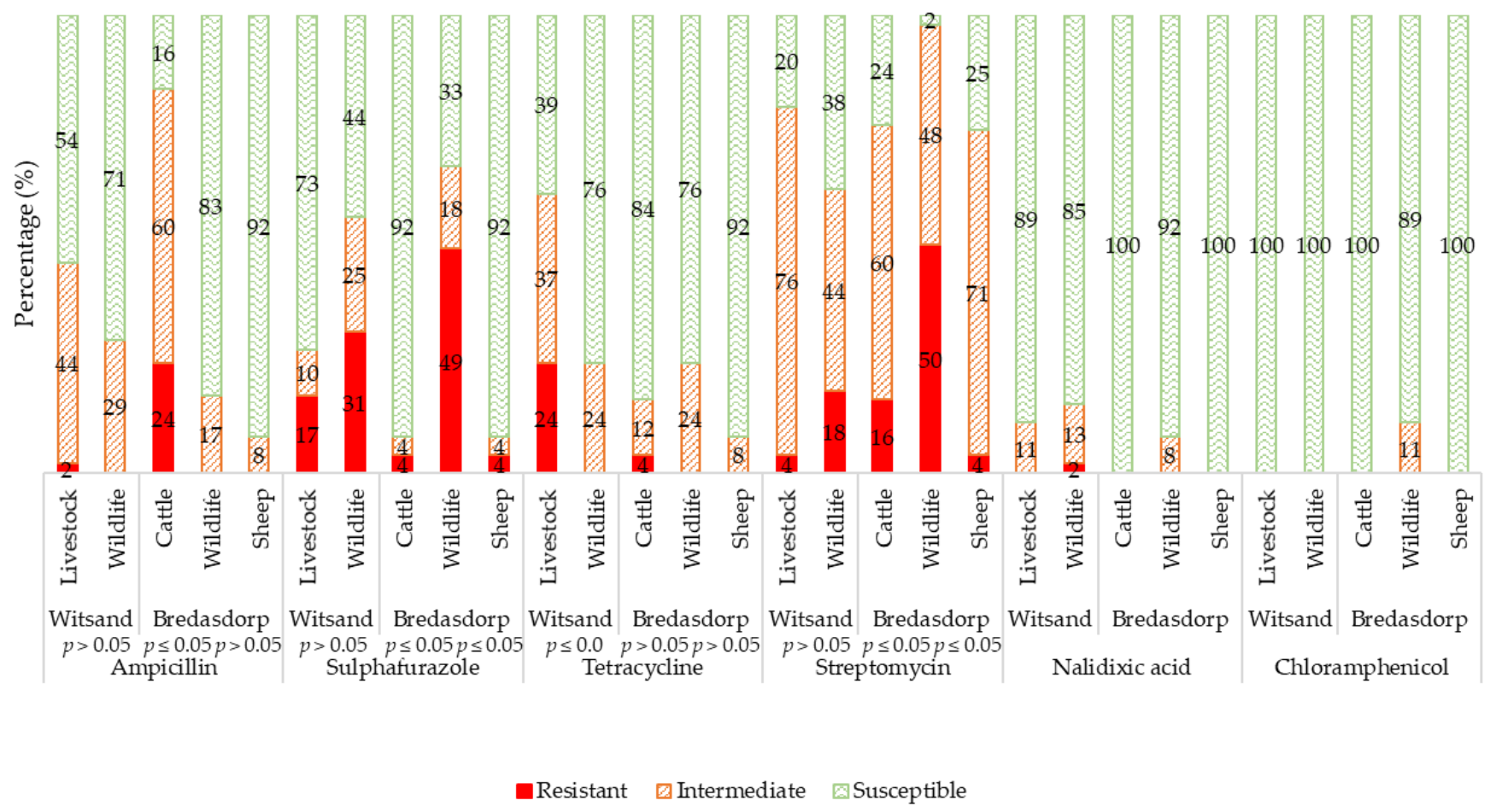

Figure 1. Antibiotic susceptibility patterns of E. coli-isolated sheep $(n=5, \mathrm{~N}=24)$ and cattle $(n=5, \mathrm{~N}=21)($ livestock), and springbok $(n=1, \mathrm{~N}=3)$ and deer $(n=4, \mathrm{~N}=19)$ (wildlife) from a co-grazing farm (Witsand) and from sheep $(n=5, \mathrm{~N}=24)$, cattle $(n=5, \mathrm{~N}=25)$, eland ( $n=5, \mathrm{~N}=24)$ and wildebeest $(n=5, \mathrm{~N}=22)$ (wildlife) from a non-co-grazing farm (Bredasdorp). $n=$ number of animals tested, $\mathrm{N}=$ total number of isolates tested.

\subsection{Genotypic Antibiotic Resistance}

The resistance genes selected for each corresponding antibiotic was selected based on some of the resistance genes that have been found to be the most common to E. coli; however, there are numerous antibiotic resistance genes, and only a small selection was used in this study. The following antibiotic-resistant genes were selected for testing: blaCMY gene (ampicillin resistance), sul1 and sul2 genes (sulphonamide resistance), aadA1 gene (streptomycin resistance), and tet $\mathrm{A}$ and tet $\mathrm{B}$ genes (tetracycline resistance). Resistant genes for chloramphenicol and nalidixic acid were not tested due to negligible phenotypic resistance levels.

In streptomycin-resistant $E$. coli, the strA-strB gene pair and the aadA gene cassette have been found to be the most common streptomycin-resistant genes $[15,16]$. There are six genes that encode for efflux pump proteins that have been identified in tetracycline-resistant E. coli strains, with the most common being tet $\mathrm{A}$, tet $\mathrm{B}$, and tet $\mathrm{C}$ [17]. The acquisition of altered target enzymes, which act as competitive inhibitors of dihydropteroate synthetase, known as dihydropteroate synthases, are the most common mechanism with which $E$. coli acquires resistance to sulphonamides $[18,19]$. There are three genes that encode for three types of these enzymes that have been characterised in Gram negatives, namely sul1, sul2, and sul3. Beta-lactam antibiotic resistance in $E$. coli is primarily mediated by the production of $\beta$-lactamase enzymes that inactivate the antibiotic [20]. Over $200 \beta$-lactamases have been identified, of which the TEM-1, TEM-2 (blaTEM gene), CTX-M (blaCTX-M gene), SHV-1 (blaSHV gene), and CMY-2 (blaCMY-2 gene) enzymes are the most common in E. coli [20]. The blaTEM1 gene has been found to be the most common determinant observed in ampicillin-resistant E. coli of animal origin [21]. The floR and cmlA for E. coli chloramphenicol resistance and gyr $\mathrm{A}$ and $g y r \mathrm{~B}, \operatorname{par} \mathrm{C}$ and $\operatorname{par} \mathrm{E}$, or cat 1 and cat 2 for nalidixic acid E. coli resistance are some of the most common antibiotic resistance genes [22-24]. These genes were not analysed in this study however, as no isolates showed phenotypic 
resistance to these two antibiotics. Table 1 shows the antibiotic resistance phenotypegenotype correlation of the E. coli isolates.

Table 1. Correlation between E. coli phenotypic antibiotic resistance and PCR results.

\begin{tabular}{|c|c|c|c|c|c|c|c|c|}
\hline \multirow{2}{*}{ Farm } & \multirow{2}{*}{ Animal } & \multirow{2}{*}{ Phenotypic Resistance ${ }^{1}$} & \multicolumn{6}{|c|}{ Genotypic Resistance } \\
\hline & & & blaCMY & sul1 & sul2 & $\operatorname{aadA1}$ & tet $\mathrm{A}$ & tet $\mathrm{B}$ \\
\hline Bredasdorp & Cattle 1 & $\operatorname{AMP}(\mathrm{I}), \mathrm{SF}(\mathrm{S}), \mathrm{ST}(\mathrm{R}), \mathrm{TE}(\mathrm{S})$ & - & - & - & + & - & - \\
\hline Bredasdorp & Cattle 2 & $\mathrm{AMP}(\mathrm{I}), \mathrm{SF}(\mathrm{S}), \mathrm{ST}(\mathrm{I}), \mathrm{TE}(\mathrm{S})$ & - & - & - & + & - & - \\
\hline Bredasdorp & Cattle 3 & $\operatorname{AMP}(\mathrm{R}), \mathrm{SF}(\mathrm{S}), \mathrm{ST}(\mathrm{I}), \mathrm{TE}(\mathrm{S})$ & + & - & - & - & - & - \\
\hline Bredasdorp & Sheep 1 & $\mathrm{AMP}(\mathrm{S}), \mathrm{SF}(\mathrm{S}), \mathrm{ST}(\mathrm{R}), \mathrm{TE}(\mathrm{I})$ & - & - & - & + & - & - \\
\hline Bredasdorp & Sheep 1 & AMP(S), SF(S), ST(I), TE(S) & + & - & - & + & - & - \\
\hline Bredasdorp & Eland 1 & AMP(S), SF(S), ST(R), TE(S) & + & - & - & + & - & - \\
\hline Bredasdorp & Eland 1 & AMP(S), SF(R), ST(I), TE (S) & - & - & + & + & - & - \\
\hline Bredasdorp & Eland 1 & $\mathrm{AMP}(\mathrm{S}), \mathrm{SF}(\mathrm{S}), \mathrm{ST}(\mathrm{R}), \mathrm{TE}(\mathrm{I})$ & - & - & - & + & + & - \\
\hline Bredasdorp & Wildebeest 1 & AMP(S), SF(S), ST(R), TE(S) & + & - & - & + & - & - \\
\hline Bredasdorp & Wildebeest 2 & AMP(S), SF(R), ST(R), TE(I) & - & - & + & + & - & - \\
\hline Bredasdorp & Wildebeest 3 & $\mathrm{AMP}(\mathrm{S}), \mathrm{SF}(\mathrm{R}), \mathrm{ST}(\mathrm{I}), \mathrm{TE}(\mathrm{S})$ & + & - & + & - & + & + \\
\hline Bredasdorp & Wildebeest 4 & $\operatorname{AMP}(\mathrm{S}), \mathrm{SF}(\mathrm{S}), \mathrm{ST}(\mathrm{R}), \mathrm{TE}(\mathrm{I})$ & + & - & - & + & - & - \\
\hline Witsand & Cattle 1 & AMP(I), SF(S), ST(I), TE(R) & - & - & - & + & + & + \\
\hline Witsand & Cattle 2 & AMP(I), SF(R), ST(R), TE(I) & - & - & - & + & - & - \\
\hline Witsand & Sheep 1 & AMP(R), SF(S), ST(I), TE(I) & + & - & - & + & - & - \\
\hline Witsand & Sheep 2 & AMP(I), SF(S), ST(I), TE(R) & - & - & - & + & - & - \\
\hline Witsand & Deer 1 & AMP(I), SF(S), ST(R), TE(S) & - & - & - & + & - & - \\
\hline Witsand & Deer 2 & AMP(S), SF(R), ST(R), TE(R) & - & + & + & + & - & + \\
\hline Witsand & Deer 3 & AMP(I), SF(R), ST(R), TE(R) & - & + & + & + & - & + \\
\hline Witsand & Springbok 1 & AMP(S), SF(S), ST(R), TE(S) & + & - & - & + & - & - \\
\hline Witsand & Springbok 2 & AMP(S), SF(S), ST(I), TE(S) & + & - & - & + & - & - \\
\hline
\end{tabular}

${ }^{1} \mathrm{AMP}$, ampicillin (blaCMY gene); SF, sulphonamide (sul1 and sul2 genes); ST, streptomycin (aadA1 gene); TE, tetracycline (tet $\mathrm{A}$ and tet $\mathrm{B}$ genes); $\mathrm{S}$, susceptible; I, intermediate; $\mathrm{R}$, resistant.

\section{Discussion}

\subsection{Phenotypic Antibiotic Resistance}

Antibiotic-resistant bacteria were found in both the livestock and wildlife faecal E. coli isolates, irrespective of whether they co-grazed (Figure 1). This suggests that antibioticresistant bacteria are present in natural environments, possibly originating from the natural reservoirs in the soil or even transferred from other nearby reservoirs, such as commercial farm effluent and transmitted to the natural environment by numerous vectors, such as birds, rodents, and rivers $[25,26]$. It has been found that antibiotic-resistant genes in the soil, produced by fungi and bacteria in the soil, such as Actinobacteria, are similar to those found in clinical settings in human pathogens, suggesting that one of the main originators of antibiotic resistance is, in fact, the environmental microbiota [10,27-29]. Other studies have also found antibiotic resistance in bacterial isolates from wildlife species and the natural environment, along with more frequent documentation of zoonotic disease infections, and suggest that wildlife could serve as a reservoir and transfer vector of antibiotic resistance of environmental origin $[5,30,31]$.

All four wildlife species in this study were predominantly grazers with minimal browsing. The grazing/browsing nature of the game species analysed in this study may also play a part in the transfer and development of antibiotic resistance as grazing allows for more direct contact with the soil bacteria, which is said to contain naturally produced antimicrobial compounds and the accompanying antibiotic-resistant genes. King and Schmidt [5] revealed that the antibiotic resistance levels of bacteria from wildebeest and zebra (grazers) were higher than those from giraffe (browser), indicating the influence of soil bacteria on antibiotic resistance.

All of the E. coli isolates showed negligible resistance towards nalidixic acid, where $0.4 \%$ of isolates were classified as resistant to nalidixic acid and $8 \%$ were classified as intermediately resistant to nalidixic acid. Nalidixic acid was the first quinolone antibiotic 
used in animals but is no longer clinically used due to its toxicity, to resistance emergence, and to the development of more effective agents [32]. Thus, it can be hypothesised that there is no significant quinolone-selective pressure present in the farming environments of Witsand or Bredasdorp to promote resistance development. Costa et al. [33], Lillehaug et al. [34], and Silva et al. [6] reported similar low antibiotic resistance levels to nalidixic acid, ranging from 0 to $14 \%$ resistance in wild animals. Rolland et al. [35] also reported that nalidixic acid resistance was uncommon in the wildlife isolates.

All of the E. coli isolates showed negligible resistance towards chloramphenicol, where no isolates were classified as resistant to chloramphenicol and only $2 \%$ were classified as intermediately resistant to chloramphenicol. Chloramphenicol is prohibited for use in food-producing animals due to its severe side-effects in humans [36]. This suggests that chloramphenicol is not used on the Bredasdorp and Witsand farms and their surroundings as no selective pressure is evident. The very low resistance in this study is consistent with other studies that detected $0-7 \%$ resistance to chloramphenicol in various wild animals and reported that resistance to chloramphenicol is rare [6,33-35].

Figure 1 shows that the E. coli isolates from the livestock and wildlife species had the highest resistance towards streptomycin, with only $13 \%$ showing susceptibility to this antibiotic. The high level of resistance to streptomycin was expected because the wildlife and livestock species, due to their grazing nature, can easily pick up streptomycin-resistant bacteria and streptomycin-resistant genes that are naturally present in the soil, produced by Actinobacteria [37]. Furthermore, streptomycin is one of the most used antibiotics in agriculture, in use since 1936. Resistance has become prevalent worldwide, where resistant clinical isolates have been evident since the late 1940s [38].

Resistance to ampicillin was the second highest from the faecal samples, where 69\% of isolates were susceptible. The significantly higher percentage of resistance towards ampicillin from the cattle isolates from the Bredasdorp farm (non-co-grazing) could have originated from the frequent application of penicillin to treat diseases (Figure 1). Penicillin is one of the most commonly used antibiotic classes in food-producing animal farming [39]. The high ampicillin resistance of the isolates from the cattle was not transferred to the sheep or wildlife.

On average, the $E$. coli isolates were $47 \%$ susceptible to sulphafurazole, a synthetic antibiotic. On both farms, the wildlife isolates showed significantly higher resistance (31\% and $49 \%$ ) to sulphafurazole than the livestock isolates (17\% and $4 \%)$. Other studies have also found $E$. coli isolates originating from natural environments to be highly resistant to sulphonamides due to the presence of a naturally occurring resistant enzyme [40]. Many indirect factors, such as the presence of heavy metals, can also be a causative factor for the onset of sulphonamide-resistant bacteria in nature [41]. Sulphonamide-resistant bacteria could also find their way into the wildlife and livestock territory via indirect pathways, such as water run-off or the application of manure from intensive farming that can be dissipated into the ground, as resistance to sulphonamides is common in intensively reared farm animals [25].

On average, there was a low level of resistance towards tetracycline, except from the E. coli isolates originating from the livestock from the Witsand farm ( $24 \%$ resistant). This resistance was not carried over to the co-grazing wildlife. Tetracycline is also a commonly used antibiotic in livestock farming, used to treat various infections and for growth promotion [42-44]. This level of resistance could also be due to tetracycline being used to treat diseases of the livestock on the Witsand farm.

On the Bredasdorp farm (no co-grazing), the only nonsignificant difference in the antibiotic resistance profiles between the non-co-grazing livestock and wildlife E. coli isolates was towards tetracycline. This is due to an overall low level of antibiotic resistance in both the livestock $(4 \%)$ and wildlife $(0 \%) \mathrm{E}$. coli isolates, leading to little variance in the data. On the contrary, on the Witsand farm (co-grazing), the only significant difference in the antibiotic resistance profiles between the co-grazing livestock ( $24 \%$ resistant) and wildlife ( $0 \%$ resistant) E. coli isolates was towards tetracycline. More specifically, the 
tetracycline resistance originated from one sheep and three cattle. This resistance pattern could be attributed to the fact that the livestock were occasionally treated therapeutically with tetracycline as required.

\subsection{Genotypic Antibiotic Resistance}

There were a few genotypic results that did not agree with the phenotypic results where the antibiotic-resistant gene was detected but the phenotypic method classified the isolate as susceptible. Antibiotic resistance genes were detected in seven of the ampicillin susceptible isolates and two of the tetracycline susceptible isolates. This discrepancy could be due to these antibiotic-resistant genes being inactive in the host, as there would be no significant antibiotic selection pressure in these more remote areas of no to low antibiotic use to warrant these genes being active or "switched on" [45].

There were also a few cases where none of the selected antibiotic-resistant genes were detected but the isolate were shown to be phenotypically resistant. This was the case in two of the sulphafurazole-resistant isolates and two of the tetracycline-resistant isolates. These discrepancies are likely due to the isolate possessing a different antibiotic-resistant gene, which was detected in this study, as there are many different antibiotic resistance genes that can confer the same phenotypic antibiotic resistance pattern. These discrepancies highlight the importance of combining genotypic and phenotypic methods for determining the antibiotic resistance patterns of bacterial species.

Katakweba et al. [46] and Navarro-Gonzalez et al. [47] did not find any significant differences in the antibiotic resistance profiles of bacteria between co-grazing wildlife and wildlife species that were isolated (non-co-grazing). In contrast, Mercat et al. [9] found that wildlife at the interface with livestock had higher resistance levels than those with no contact with livestock, suggesting a transfer in antibiotic resistance through co-grazing. These disputed points highlight the complexity of antibiotic resistance and transfer in nature, a highly complex ecosystem.

\section{Materials and Methods}

\subsection{Study Area and Sample Collection}

Springbok, fallow deer, Angus cattle, and Merino sheep faecal samples were collected from a farm in Witsand, Western Cape, South Africa. The wildlife species were free to cograze with the livestock species. Both the livestock and wildlife grazed and drank (natural streams and ground/borehole water) on the farm's natural resources, although in times of drought, the livestock were supplied with supplementary feed. The supplementary feed did not contain any antibiotics. This farm is a commercial free-range farm where the livestock are sold for slaughter and the wildlife are only slaughtered for personal use. The livestock are given penicillin or tetracycline as required to treat diseases. The wildlife do not receive any medication.

Eland, black wildebeest, Angus cattle, and Merino sheep faecal samples were collected from a farm in Bredasdorp, Western Cape, South Africa. The wildlife species were separated from the livestock by a fenced off region that did not allow any wildlife to leave the fenced off area. The wildlife grazed on pastures and drank from the farm's dam. The livestock were fed a supplementary feed daily and drank from the ground/borehole water, which was pumped into drinking troughs. The supplementary feed did not contain any antibiotics. This farm is also a commercial free-range farm where the livestock are sold live or slaughtered and the wildlife are infrequently sold live for breeding. Similar to the Witsand farm, the livestock on the Bredasdorp farm also receive penicillin or tetracycline as required to treat diseases. The wildlife also do not receive any medication.

A summary of the sample species, farm location, type of farm, and number of samples collected is shown in Table 2. All four of the wildlife species are ungulates and are all grazers or mixed grazers-browsers. 
Table 2. Details of the wildlife and livestock samples used in this study.

\begin{tabular}{cccc}
\hline Wildlife Species & Farm Location & Farm Type & Number of Faecal Samples \\
\hline Springbok (Antidorcas marsupialis) & Witsand & Co-grazing & 5 \\
Fallow deer (Dama dama) & Witsand & Co-grazing & 5 \\
Sheep (Ovis aries) & Witsand & Co-grazing & 5 \\
Cattle (Bos taurus) & Witsand & Co-grazing & 5 \\
Eland (Taurotragus oryx) & Bredasdorp & No co-grazing & 5 \\
Black wildebeest (Connochaetes gnou) & Bredasdorp & No co-grazing & 5 \\
Sheep (Ovis aries) & Bredasdorp & No co-grazing & 5 \\
Cattle (Bos taurus) & Bredasdorp & No co-grazing & 5 \\
\hline
\end{tabular}

Livestock faecal $(\approx 20 \mathrm{~g})$ samples were collected from the ground shortly after deposition into sterile sample containers. All of samples from the same farm were collected during the same time period on the same day to avoid possible repetitive sampling.

Wildlife faecal $(\approx 20 \mathrm{~g})$ samples were aseptically collected in a sterile container from the middle of the small intestine after evisceration from recently slaughtered animals. All of collected samples were then transported on ice at $\approx 4{ }^{\circ} \mathrm{C}$ to the university's laboratory freezer $\left(-20^{\circ} \mathrm{C}\right)$ within $24 \mathrm{~h}$ of sampling. Before analysis commenced, the samples were defrosted at room temperature.

\subsection{Isolation of Escherichia coli}

Approximately $90 \mathrm{~mL}$ of buffered peptone water (Merck Biolab, Modderfontein, South Africa) and $10 \mathrm{~g}$ of faecal matter was aseptically added into a stomacher bag and homogenised for $2 \mathrm{~min}$ using a stomacher device. The sample was then incubated at $37^{\circ} \mathrm{C}$ for $12-14 \mathrm{~h}$. This resuscitation step allows for better recovery of bacterial cells due to frozen storage [48].

The pour plate technique was used, using a violet red bile dextrose agar (VRBDA) (Merck Biolab, Modderfontein, South Africa) and $10^{-4}$ and $10^{-5}$ dilutions of the original sample. These dilutions were found to produce single colonies in the range of 25 to 250 colonies per plate, thus allowing single colonies to be easily obtained. The plates were inverted and incubated overnight at $37^{\circ} \mathrm{C}$.

Characteristic colonies from the VRBDA plates were streaked onto an eosin methylene blue agar (Oxoid, Hampshire, UK). The plates were inverted and incubated overnight at $37^{\circ} \mathrm{C}$.

Five presumptive E. coli colonies were selected per animal species, and their identities were confirmed using Gram's stain and the citrate utilisation test using Simmons citrate agar (Oxoid, Hampshire, UK). Glycerol stock cultures were made of the confirmed E. coli isolates.

\subsection{Antibiotic Susceptibility Testing}

The Kirby-Bauer disk diffusion method was used according to the Clinical and Laboratory Standards Institute (CLSI) 2018 guidelines, using fresh overnight cultures grown on nutrient agars (Merck Biolab, Modderfontein, South Africa). A quality control strain, E. coli ATCC 25922 (Thermo Fisher Scientific, Lake Charles, LA, USA), and a negative control plate were used.

The antibiotic discs (Oxoid, Johannesburg, South Africa) containing ampicillin (10 $\mu \mathrm{g})$, chloramphenicol $(30 \mu \mathrm{g})$, nalidixic acid $(30 \mu \mathrm{g})$, streptomycin $(10 \mu \mathrm{g})$, sulphafurazole $(300 \mu \mathrm{g})$, and tetracycline $(30 \mu \mathrm{g})$ were placed on the inoculated Mueller-Hinton agar (Merck Biolab, Modderfontein, South Africa) plates using an automatic six-disc dispenser (Oxoid, Johannesburg, South Africa).

The selection of antibiotics were chosen based on those that are commonly used in the animal farming sector in South Africa as well as nalidixic acid and chloramphenicol, as these two antibiotics are no longer used, where the latter has been banned for use in animal farming. 
The bacteria's antibiotic susceptibility profile was determined using the diameter of the zone of inhibition and the parameters published by the CLSI 2018. The disc diffusion test was performed on five E. coli isolates that were isolated from each animal.

\subsection{Statistical Analysis}

The categorised results were analysed using one-way analysis of variance (ANOVA) using the Statistica 13.2 software (Tibco, Palo Alto, CA, USA). Levene's test was applied to determine homogeneity of variance. The main effect was the practice of co-grazing and non-co-grazing. If the group means were significantly different within the groups, post hoc tests were performed to determine where the differences occurred within each group. Significant results were identified by least significant means (LSM) with a 95\% confidence interval.

\subsection{Gene Detection}

DNA from fresh overnight cultures was extracted using a crude extraction method involving boiling and lysis buffer. The extracted DNA concentration and quality were established using a Nanodrop- 1000 spectrophotometer (Thermo Fisher Scientific, Wilmington, DE, USA) before PCR commenced.

Polymerase chain reaction (PCR) was used to detect a selection of antibiotic-resistant genes in a representative selection of isolates showing phenotypic resistance. The genes selected and the primers and reaction conditions are listed in Table 3. The reactions were performed in duplicate. Each reaction $(25 \mu \mathrm{L})$ consisted of 1 unit of Ampliqon multiplex TEMPase $2 \times$ Master Mix (Ampliqon, Ondense, Denmark), $1 \mu \mathrm{L}$ of template DNA, $0.2 \mu \mathrm{M}$ each of the forward and reverse primers (Inqaba Biotec, Muckleneuk, South Africa), and the remaining volume distilled nuclease-free water (Inqaba Biotec, Muckleneuk, South Africa).

Table 3. PCR conditions for detection of the selected antibiotic resistance genes.

\begin{tabular}{|c|c|c|c|c|c|}
\hline Antibiotic & Gene & $\begin{array}{l}\text { Primers F: } 5^{\prime}-3^{\prime} \\
\text { Primers R: } 5^{\prime}-3^{\prime}\end{array}$ & bp & Reaction Conditions & Reference \\
\hline \multirow{2}{*}{ 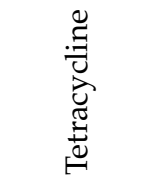 } & tet $\mathrm{A}$ & $\begin{array}{l}\text { F: GGCGGTCTTCTTCATCATGC } \\
\text { R: CGGCAGGCAGAGCAAGTAGA }\end{array}$ & 502 & \multirow{2}{*}{$\begin{array}{c}15 \mathrm{~min} \text { at } 95^{\circ} \mathrm{C} ; 35 \text { cycles } \\
\text { of: } 20 \mathrm{~s} \text { at } 95^{\circ} \mathrm{C}, 40 \mathrm{~s} \text { at } \\
66^{\circ} \mathrm{C}, 40 \mathrm{~s} \text { at } 72^{\circ} \mathrm{C} ; 4 \mathrm{~min} \\
\text { at } 72^{\circ} \mathrm{C} \text {. }\end{array}$} & \multirow{2}{*}{ Adapted from [15] } \\
\hline & tet $\mathrm{B}$ & $\begin{array}{l}\text { F: CATTAATAGGCGCATCGCTG } \\
\text { R: TGAAGGTCATCGATAGCAGG }\end{array}$ & 930 & & \\
\hline \multirow{2}{*}{ 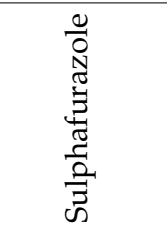 } & sul1 & $\begin{array}{l}\text { F: CGGCGTGGGCTACCTGAACG } \\
\text { R: GCCGATCGCGTGAAGTTCCG }\end{array}$ & 433 & \multirow{2}{*}{$\begin{array}{c}15 \mathrm{~min} 95^{\circ} \mathrm{C} ; 30 \text { cycles of: } \\
20 \mathrm{~s} \text { at } 95^{\circ} \mathrm{C}, 40 \mathrm{~s} \text { at } 66^{\circ} \mathrm{C}, \\
40 \mathrm{~s} \text { at } 72^{\circ} \mathrm{C} ; 4 \mathrm{~min} \\
\text { at } 72^{\circ} \mathrm{C} .\end{array}$} & \multirow[t]{2}{*}{ Adapted from [25] } \\
\hline & sul2 & $\begin{array}{l}\text { F: CGGCATCGTCAACATAACCT } \\
\text { R: TGTGCGGATGAAGTCAGCTC }\end{array}$ & 721 & & \\
\hline 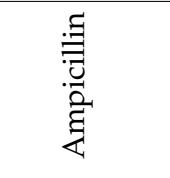 & blaCMY & $\begin{array}{l}\text { F: GACAGCCTCTTTCTCCACA } \\
\text { R: TGGACACGAAGGCTACGTA }\end{array}$ & 1000 & $\begin{array}{l}15 \text { min at } 94{ }^{\circ} \mathrm{C} ; 30 \text { cycles } \\
\text { of: } 1 \text { min at } 94{ }^{\circ} \mathrm{C}, 1 \text { min at } \\
55^{\circ} \mathrm{C}, 1 \text { min at } 72{ }^{\circ} \mathrm{C} \text {; } \\
10 \text { min at } 72{ }^{\circ} \mathrm{C} \text {. }\end{array}$ & [25] \\
\hline 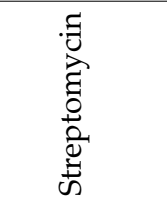 & $\operatorname{aad} \mathrm{A} 1$ & $\begin{array}{l}\text { F: GTGGATGGCGGCCTGAAGCC } \\
\text { R: AATGCCCAGTCGGCAGCG }\end{array}$ & 525 & $\begin{array}{c}15 \text { min at } 95^{\circ} \mathrm{C} ; 35 \text { cycles } \\
\text { of: } 1 \text { min at } 94{ }^{\circ} \mathrm{C}, 1 \text { min at } \\
60{ }^{\circ} \mathrm{C}, 1 \text { min at } 72{ }^{\circ} \mathrm{C} \text {; } \\
7 \text { min at } 72^{\circ} \mathrm{C} \text {. }\end{array}$ & Adapted from [15] \\
\hline
\end{tabular}

The PCR product was applied to a 1.2\% agarose gel (Lonza SeaKem, Rockland, ME, USA) stained with EZ-Vision ${ }^{\circledR}$ in-gel solution DNA dye (Amresco, Solon, OH, USA), using electrophoresis run at $85 \mathrm{~V}$ for 60-90 min and then visualized using the Bio-Rad Gel Doc XR + System (Bio-Rad, Hercules, CA, USA) in combination with Image Lab Software V5.2.1. 
A 100 bp DNA ladder was used (New England BioLabs Inc., Ipswich, MA, USA) as a reference marker.

\section{Conclusions}

Although the overall results of this study suggest that, on these two farms in the Western Cape (South Africa), co-grazing may result in a transfer of antibiotic resistance bacteria and genetic elements between co-grazing wildlife and livestock and that separating livestock and wildlife may help to reduce this transfer, this remains a complex phenomenon, which warrants further investigation.

\section{Limitations of Study}

This study was limited by the fact that neither the livestock nor wildlife isolates had significantly high antibiotic resistance levels, lessening the potential effect of transmission within the livestock-wildlife interface. This study was also limited in the number of samples and farms used, in the number of antibiotics used for the analysis, and in the number of antibiotic resistance genes detected. Therefore, additional studies are recommended to confirm whether the practice of co-grazing can lead to the transfer and exchange of antibiotic resistance and, potentially, shared pathogens and diseases.

Author Contributions: Conceptualization, M.S.v.d.H., P.A.G. and L.C.H.; methodology, M.S.v.d.H., P.A.G. and L.C.H.; formal Analysis, M.S.v.d.H.; data curation, M.S.v.d.H., P.A.G. and L.C.H.; writingoriginal draft, M.S.v.d.H.; writing—review and editing, M.S.v.d.H., P.A.G. and L.C.H.; supervision, P.A.G. and L.C.H. All authors have read and agreed to the published version of the manuscript.

Funding: This research was supported by the South African Research Chairs Initiative (SARChI) and was funded by the South African Department of Science and Technology (UID number: 84633), as administered by the National Research Foundation (NRF) of South Africa as well as Stellenbosch University. The financial assistance of the NRF and the Department of Trade and Industry's (DTI) THRIP program (THRIP/64/19/04/2017) as well as Wildlife Ranching South Africa (WRSA) towards this research is hereby acknowledged. The opinions expressed and conclusions derived are those of the authors and are not necessarily attributed to the NRF.

Institutional Review Board Statement: All animals were harvested and sampled according to the standard operating procedure approved by the Stellenbosch University Animal Care and Use Committee (SU-ACUM14-001SOP).

Data Availability Statement: The raw data presented in this study are available upon request to the corresponding author.

Conflicts of Interest: The authors declare no conflict of interest.

\section{References}

1. Vittecoq, M.; Godreuil, S.; Prugnolle, F.; Durand, P.; Renaud, N.; Arnal, A.; Aberkane, S.; Gauthier-Clerc, M. Antimicrobial resistance in wildlife. J. Appl. Ecol. 2016, 53, 519-529. [CrossRef]

2. Woolhouse, M.; Ward, M.; van Bunnik, B.; Farrar, J. Antimicrobial resistance in humans, livestock and the wider environment. Philos. Trans. R. Soc. B Biol. Sci. 2015, 370, 1-7. [CrossRef] [PubMed]

3. Bekker, J.L. A Food Safety Plan for the Game Meat Industry in South Africa. Ph.D. Thesis, Stellenbosch University, Stellenbosch, South Africa, 2011.

4. Dias, D.; Torres, R.T.; Kronvall, G.; Fonsec, C.; Mendo, S.; Caetano, T. Assessment of antibiotic resistance of Escherichia coli isolates and screening of Salmonella spp. in wild ungulates from Portugal. Res. Microbiol. 2015, 166, 584-593. [CrossRef] [PubMed]

5. King, T.L.B.; Schmidt, S. Assessment of three indigenous South African herbivores as potential reservoirs and vectors of antibiotic-resistant Escherichia coli. Eur. J. Wildl. Res. 2017, 63, 44. [CrossRef]

6. Silva, N.; Igrejas, G.; Figueiredo, N.; Gonçalves, A.; Radhouani, H.; Rodrigues, J.; Poeta, P. Molecular characterization of antimicrobial resistance in Enterococci and Escherichia coli isolates from European wild rabbit Oryctolagus cuniculus. Sci. Total Environ. 2010, 408, 4871-4876. [CrossRef] [PubMed]

7. Bengis, R.G.; Kock, R.A.; Fischer, J. Infectious animal diseases: The wildlife/livestock interface. Rev. Sci. Tech. 2002, 21, 53-65. [PubMed]

8. Food and Agricultural Organization. Bushmeat Consumption, Wildlife Trade and Global Public Health Risks. Available online: http:/ / www.fao.org/ag/againfo/programmes/en/empres/news_151010.html (accessed on 30 March 2020). 
9. Mercat, M.; Clermont, O.; Massot, M.; Ruppe, E.; Garine-wichatitsky, M.; De Miguel, E. Escherichia coli population structure and antibiotic resistance at a buffalo/cattle interface in Southern Africa. Appl. Environ. Microbiol. 2016, 82, 1459-1467. [CrossRef] [PubMed]

10. Allen, H.K.; Donato, J.J. Call of the wild: Antibiotic resistance genes in natural environments. Nat. Rev. Microbiol. 2010, 10, 1-9. [CrossRef] [PubMed]

11. Rhyan, J.C.; Spraker, T.R. Emergence of diseases from wildlife reserviours. Vet. Pathol. 2010, 47, 34-39. [CrossRef] [PubMed]

12. Morgan, E.R.; Lundervold, M.; Medley, G.F.; Shaikenov, B.S.; Torgerson, P.R.; Milner-Gulland, E.J. Assessing risks of disease transmission between wildlife and livestock: The Saiga antelope as a case study. Biol. Conserv. 2016, 131, 244-254. [CrossRef]

13. Metzler-Zebeli, B.U.; Lawlor, P.G.; Magowan, E.; Zebeli, Q. Effect of freezing conditions on fecal bacterial composition in pigs. Animals 2016, 6, 18. [CrossRef]

14. Radhouani, H.; Silva, N.; Poeta, P.; Torres, C.; Correia, S.; Igrejas, G. Potential impact of antimicrobial resistance in wildlife, environment, and human health. Front. Microbiol. 2014, 5, 1-12. [CrossRef] [PubMed]

15. Boerlin, P.; Travis, R.; Gyles, C.L.; Reid-Smith, R.; Janecko, N.; Lim, H.; Nicholson, V.; McEwen, S.A.; Friendship, R.; Archambault, M. Antimicrobial resistance and virulence genes of Escherichia coli isolates from swine in Ontario. Appl. Environ. Microbiol. 2005, 71, 6753-6761. [CrossRef]

16. Sunde, M.; Norström, M. The genetic background for streptomycin resistance in Escherichia coli influences the distribution of MICs. J. Antimicrob. Chemother. 2005, 56, 89-90. [CrossRef]

17. Wilkerson, C.; Samadpour, M. Antibiotic resistance and distribution of tetracycline resistance genes in Escherichia coli O157:H7 isolates from humans and bovines. Antimicrob. Agents Chemother. 2004, 48, 1066-1067. [CrossRef]

18. Frank, T.; Gautier, V.; Talarmin, A.; Bercion, R.; Arlet, G. Characterisation of sulphonamide resistance genes and class integrin gene cassettes in Enterobacteriaceae, Central African Republic (CAR). J. Antimicrob. Chemother. 2007, 59, 742-745. [CrossRef]

19. Tadesse, D.A.; Zhao, S.; Tong, E.; Ayers, S.; Singh, A.; Bartholomew, M.J.; McDermott, P.F. Antimicrobial drug resistance in Escherichia coli from humans and food animals, United States, 1950-2002. Emerg. Infect. Dis. 2012, 18, 741-749. [CrossRef] [PubMed]

20. Lachmayr, K.L.; Kerkhof, L.J.; DiRienzo, A.G.; Cavanaugh, C.M.; Ford, T.E. Quantifying nonspecific TEM $\beta$-lactamase (blaTEM) genes in a wastewater stream. Appl. Environ. Microbiol. 2009, 75, 203-211. [CrossRef] [PubMed]

21. Mirzaagha, P.; Louie, M.; Read, R.R.; Sharma, R.; Yanke, L.J.; Topp, E.; McAllister, T.A. Characterization of tetracycline- and ampicillin-resistant Escherichia coli isolated from the feces of feedlot cattle over the feeding period. Can. J. Microbiol. 2009, 55, 750-761. [CrossRef]

22. Bischoff, M.K.; White, D.G.; McDermott, P.F.; Zhao, S.; Gaines, S.; Maurer, J.J.; Nisbet, D.J. Characterisation of chloramphenicol resistance in beta-hemolytic Escherichia coli associated with diarrhoea in neonatal swine. J. Clin. Microbiol. 2002, 40, 389-394. [CrossRef] [PubMed]

23. Sáenz, Y.; Briñas, L.; Domíngue, E.; Ruiz, J.; Zarazage, M.; Vila, J.; Torres, C. Mechanisms of resistance in multiple-antibioticresistant Escherichia coli strains of human, animal, and food origins. Antimicrob. Agents Chemother. 2004, 48, 3996-4001. [CrossRef]

24. Gonçalves, A.; Igrejas, G.; Radhouani, H.; Santos, T.; Monteiro, R.; Pacheco, R.; Alcaide, E.; Zorrilla, I.; Serra, R.; Torres, C.; et al. Detection of antibiotic resistance Enterococci and Escherichia coli in free range Inberian Lynx Lynx Pardinus. Sci. Total Environ. 2013, 456-457, 115-119. [CrossRef] [PubMed]

25. Kozak, G.K.; Boerlin, P.; Janecko, N.; Reid-Smith, R.J.; Jardine, C. Antimicrobial resistance in Escherichia coli isolates from swine and wild small mammals in the proximity of swine farms and in natural environments in Ontario, Canada. Appl. Environ. Microbiol. 2009, 75, 559-566. [CrossRef] [PubMed]

26. Sousa, M.; Silva, N.; Igrejas, G.; Silva, F.; Sargo, R.; Alegria, N.; Benito, D.; Go, P.; Torres, C.; Lozano, C.; et al. Antimicrobial resistance determinants in Staphylococcus spp. recovered from birds of prey in Portugal. Vet. Microbiol. 2014, 171, 436-440. [CrossRef] [PubMed]

27. Bemier, S.P.; Surette, M.G. Concentration-dependent activity of antibiotics in natural environments. Front. Microbiol. 2013, 4, 1-14.

28. Berglund, B. Environmental dissemination of antibiotic resistance genes and correlation to anthropogenic contamination with antibiotics. Infect. Ecol. Epidemiol. 2015, 5, 1-10. [CrossRef] [PubMed]

29. Martinez, J.L. Natural antibiotic resistance and contamination by antibiotic resistance determinants: The two ages in the evolution of resistance to antimicrobials. Front. Microbiol. 2012, 3, 1-3. [CrossRef]

30. Cole, D.; Drum, D.J.V.; Stallknecht, D.E.; White, D.G.; Lee, M.D.; Ayers, S.; Sobsey, M.; Maurer, J.J. Free-living Canada geese and antimicrobial resistance. Emerg. Infect. Dis. 2005, 11, 935-939. [CrossRef]

31. Mariano, V.; McCrindle, C.M.E.; Cenci-Goga, B.; Picard, J.A. Case-control study to determine whether river water can spread tetracycline resistance to unexposed Impala Aepyceros melampus in Kruger National Park South Africa. Appl. Environ. Microbiol. 2009, 75, 113-118. [CrossRef]

32. World Health Organisation. Use of Quinolones in Food Animals and Potential Impact on Human Health; World Health Organisation: Geneva, Switzerland, 1998; pp. 1-129.

33. Costa, D.; Poeta, P.; Sáenz, Y.; Vinué, L.; Coelho, A.C.; Matos, M.; Rojo-Bezares Rodrigues, J.; Torres, C. Mechanisms of antibiotic resistance in Escherichia coli isolates recovered from wild animals. Microb. Drug Resist. 2008, 14, 71-78. [CrossRef]

34. Lillehaug, A.; Bergsjø, B.; Schau, J.; Bruheim, T.; Vikøren, T.; Handeland, K. Campylobacter spp., Salmonella spp., verocytotoxic Escherichia coli, and antibiotic resistance in indicator organisms in wild cervids. Acta Vet. Scand. 2005, 46, 23-32. [CrossRef] 
35. Rolland, R.M.; Hausfater, G.; Marshall, B.; Levy, S.B. Antibiotic resistant bacteria in wild primates: Increased prevalence in baboons feeding on human refuse. Appl. Environ. Microbiol. 1985, 49, 791-794. [CrossRef] [PubMed]

36. Schwarz, S.; Kehrenberg, C.; Doublet, B.; Cloeckaert, A. Molecular basis of bacterial resistance to chloramphenicol and florfenicol. FEMS Microbiol. Rev. 2004, 28, 519-542. [CrossRef]

37. Cantas, L.; Shah, S.Q.A.; Cavaco, L.M.; Manala, C.M.; Walsh, F.; Popowska, M.; Garelick, H.; Bürgmann, H.; Serum, H. A brief multi-disciplinary review on antimicrobial resistance in medicine and its linkage to the global environmental microbiota. Front. Microbiol. 2013, 4, 1-14. [CrossRef] [PubMed]

38. Chadha, T. Antibiotic resistant genes in natural environment. Agrotechnology 2013, 1, 1-3. [CrossRef]

39. Economou, V.; Gousia, P. Agriculture and food animals as a source of antimicrobial-resistant bacteria. Infect. Drug Resist. 2015, 8 , 49-61. [CrossRef] [PubMed]

40. Wise, E.M.; Abou-Doni, M.M. Sulfonamide resistance mechanism in Escherichia coli: R plasmids can determine sulphonamideresistant dihydropteroate synthases. Proc. Natl Acad. Sci. USA 1975, 72, 2621-2625. [CrossRef] [PubMed]

41. Na, G.; Lu, Z.; Gao, H.; Zhang, L.; Li, Q.; Li, R.; Yang, F.; Huo, C.; Yao, Z. The effect of environmental factors and migration dynamics on the prevalence of antibiotic-resistant Escherichia coli in estuary environments. Sci. Rep. 2018, 8, 1-9. [CrossRef]

42. Bryan, A.; Shapir, N.; Sadowsky, M.J. Frequency and distribution of tetracycline resistance genes in genetically diverse, nonselected, and nonclinical Escherichia coli strains isolated from diverse human and animal sources. Appl. Environ. Microbiol. 2004, 70, 2503-2507. [CrossRef]

43. Fan, W.; Hamilton, T.; Webster-Sesay, S.; Nikolich, M.P.; Lindler, L.E. Mulitplex real-time SYBR green I PCR assay for detection of tetracycline efflux genes of Gram-negative bacteria. Mol. Cell. Probes 2006, 21, 245-256. [CrossRef]

44. Michalova, E.; Novotna, P.; Schlegelova, J. Tetracyclines in veterinary medicine and bacterial resistance to them. Veterinární Med. 2004, 49, 79-100. [CrossRef]

45. Gilmore, K.S.; Gilmore, M.S.; Sahn, D.F. Methicillin resistance in Staphylococcus aureus. In Bacterial Resistance to Antimicrobials, 2nd ed.; CRC Press: Boca Raton, FL, USA, 2008; pp. 291-296.

46. Katakweba, A.A.S.; Møller, K.S.; Muumba, J.; Muhairwa, A.P.; Damborg, P.; Rosenkrantz, J.T.; Minga, U.M.; Mtambo, M.M.A.; Olsen, J.E. Antimicrobial resistance in faecal samples from buffalo, wildebeest and zebra grazing together with and without cattle in Tanzania. J. Appl. Microbiol. 2015, 118, 966-975. [CrossRef] [PubMed]

47. Navarro-Gonzalez, N.; Porrero, M.C.; Mentaberre, G.; Serrano, E.; Mateos, A.; Domínguez, L.; Lavína, S. Antimicrobial resistance in indicator Escherichia coli isolates from free-ranging livestock and sympatric wild ungulates in a natural environment northeastern Spain. Appl. Environ. Microbiol. 2013, 79, 6184-6186. [CrossRef]

48. Bloch, N.; Sidjabat-Tambunan, H.; Tratt, T.; Bensink, J.; Lea, K.; Frost, A.J. The enumeration of coliforms and E. coli on naturally contaminated beef: A comparison of the Petrifilm ${ }^{\mathrm{TM}}$ method with the Australian standard. Meat Sci. 1996, 43, 187-193. [CrossRef] 